\title{
Budgetary Change in Authoritarian and Democratic Regimes
}

\begin{abstract}
:
We compare patterns of change in budgetary commitments by countries during periods of democracy and authoritarianism. Previous scholarship has focused almost exclusively on democratic governments, finding evidence of punctuated equilibria. Authoritarian regimes may behave differently, both because they may operate with fewer institutional barriers to choice and because they have fewer incentives to gather and respond to policy-relevant information coming from civil society. By analysing public budgeting in Brazil, Turkey, Malta, and Russia before and after their transitions from or to democracy, we can test punctuated equilibrium theory under a variety of governing conditions. Our goal is to advance the understanding of the causes of budgetary instability by leveraging contextual circumstances to push the theory beyond democracies and assess its broader applicability.
\end{abstract}

Keywords: Authoritarianism, budgeting, democracy, public policy, punctuated equilibrium. 
PET (punctuated equilibrium theory) describes how, as a consequence of disproportionate information processing, public policies alternate between long periods of stasis where negative feedback forces maintain the status quo and brief but dramatic periods of change. While the theory accurately describes a broad range of policy activities, studies of PET have looked almost exclusively at Western democracies, where the wide availability of public budgets and other policy indicators facilitate longitudinal analysis. For example, the 2009 article 'A General Empirical Law of Public Budgets' (Jones et al. 2009) focused on only European and North American democracies.

We test PET across different political regimes. First, in the context of authoritarianism and democracy, we analyse public budgeting in Russia from 1998 to 2014, Turkey from 1970 to 2004, and Brazil from 1964 to 2010 - periods including episodes of democracy and nondemocracy in each country. We then look at historical data from Malta during periods of colonial rule by the British (1826-1921), colonial self-government (1922-1936), and during a more recent period (2001-11) since that country's 1964 independence.

Democratic and other regimes might differ with regard to budgeting in two opposite ways. On the one hand, autocrats face fewer public and formal checks and balances, possibly allowing them to respond quickly in reaction to shifting contexts; this could be called the 'institutional efficiency' hypothesis. One the other hand, democracies may have higher capacity to gather information about social and other issues because of mechanisms associated with electoral accountability, as well as stronger and more independent civil society organizations including the press; the 'informational advantage' hypothesis.

Under the efficiency hypothesis, an autocrat, working with few institutional constraints such as generating a majority in a democratically elected and independent legislature, should be 
able to shift spending priorities when advisors recognize the need to do so. This decision-making efficiency would lead us to expect fewer punctuations in regimes where power is concentrated in a decision-making élite who can operate with broad institutional latitude. Institutional and decision-making frictions are lower, so decisions should be more efficient. Indeed, 'making the trains run on time' is one of the main justifications for authoritarian rule, and democracies are often criticized for high decision costs if not deadlock and stalemate.

Democracies have an advantage however when it comes to gathering information: they have many uncensored sources of demands, information, and feedback about the impact of current policies through a more vibrant network of civil society organizations, including political parties staffed by officials anxious to 'feel the pulse' of various constituencies. Furthermore, a bureaucratic network gives democratic leaders the capacity to respond to information once it has been processed. By contrast, authoritarian regimes may be less capable of gathering, processing, and responding to information about societal problems because they have fewer independent sources of information, and indeed they may suppress certain kinds of information or have highly focused policy priorities. Subsequently, we would expect that the magnitude of punctuation in public budgets during periods of authoritarianism would be greater, as governments either fail to gather or ignore signals for longer than would be possible in democracies, only acting when problems grow so large that they threaten the stability of the regime.

Budget data for each country is compiled from various public records and to our knowledge the datasets assembled here are the longest and most accurate publicly available account of budgeting in any of the four countries. Empirical tests are straightforward and designed to distinguish between the two hypotheses. Using Freedom House scores, we classify 
regimes as either 'Not Free,' 'Partly Free,' or 'Free' for each year of data. Then, for each country, we draw a distribution of budgetary changes corresponding to the different freedom scores. (For Malta, where our data pre-dates the Freedom House scores, we consider the period of self-government as more politically open relative to the period of British colonial rule.) Since our tests are pre- and post-transition within four countries that have experienced changes in forms of government, we effectively control for many other factors including culture, size of the budget, and complexity of the social issues facing the nation.

Evidence strongly supports the information hypothesis, suggesting that any advantage authoritarian regimes gain through institutional efficiency is outweighed by informational constraints. We replicate these findings in the on-line appendix using alternative regimeclassification systems to divide the data, rather than Freedom House. These include Polity IV's assessment of political competition, Unified Democracy Scores (U-Dem), Varieties of Democracy scores (V-Dem), and, finally, by simply using the historical record to identify periods of regime transition. Collectively the results favour the information hypothesis; evidence that our findings using Freedom House scores are robust.

The relative advantage that democratic regimes with a free system of the press and active social mobilizations have with regard to signal detection and problem recognition are poorly understood. Indeed, we know of no budgetary research that systematically compares political regimes with regard to these issues. Our contribution is to develop Punctuated Equilibrium Theory by looking at the impact of institutional forms on patterns of budget reallocations. For all the regimes we examine there is a combination of policy stability and punctuations, implying that the distinction between authoritarianism and democracy (or different forms of democracy) 
is, in a sense, not fundamental for understanding budget allocations. ${ }^{1}$ The levels of punctuation observed differ substantially, however. Theoretically we would expect democracies to have greater informational capacity than other political regimes and this idea finds support in the data. Indeed, the findings suggest that democratic informational efficiency is more important than non-democratic institutional efficiency. Relative budgetary stability can be added to the long list of attributes that favour democratic governance over its alternatives.

\section{Punctuated equilibrium}

Baumgartner and Jones developed PET in 1993 through in-depth case studies of particular policy issues, such as nuclear energy and pesticide use. They found that policy changes in these areas were predominately incremental, but that occasionally radically new ideas would gain momentum causing a tidal shift in government policies toward these issues. In later work (2005) they introduced a more generalized model to demonstrate that government policymaking is a fundamentally erratic process; it is characterized by long periods of equilibrium intermittently punctuated by dramatic changes. Their argument was this: because policymakers are boundedly rational and the processing capacity of political institutions is constrained by rules, governments are disproportionate processors of information. The effects on policy change are two-fold. On one hand, an extreme allegiance to the status quo is built into the system. If attention is scarce, most issues most of the time will be ignored and it is difficult to justify changing the status quo in the absence of attention. But, on the other hand, issues cannot be ignored indefinitely; societal

\footnotetext{
${ }^{1}$ Existing PET scholarship underscores the fact that electoral change is not the only - or even primary driver of policy change: 'policy changes frequently stem from the emergence of new information or changes in the social or economic environment that are not so simply related to the electoral process' (Baumgartner, Jones and Wilkerson 2011: 948). That these processes are also found in non-democratic systems should temper any surprise at the distributional similarity of budget allocations across regime types.
} 
problems will grow worse over time and eventually need to be addressed. When an issue finally receives attention, policymakers may be forced to enact dramatic policy changes, if only to catch up for the lack of moderate adjustments they failed to make as the problem slowly developed. Thus the model describes a system characterized by friction, where negative feedback forces are predominant, but occasionally give way to periods of rapid self-reinforcing change. With policymakers responding only to a limited number of urgent problems at any given time, issues beneath a threshold level of urgency are put on the back burner as attention is focused on the most pressing issues; there are always more issues that deserve attention than time to attend to them.

The implications of the model are that policy changes will fall into one of two categories: incremental when the status quo prevails, and dramatic during rare periods of imbalance. Empirical support for this prediction is substantial. A long line of scholarship finds that distributions of changes in public budgets display a punctuated equilibrium pattern, characterized by high central peaks, 'weak shoulders', and very long tails (Baumgartner et.al. [2009]; Breunig and Koski [2006]; Breunig, Koski, and Mortensen [2010]; Jones and Baumgartner [2005]; Jones et.al. [2009]; Jones, Sulkin, and Larsen [2003]; Robinson et.al. [2014]). This research focuses on kurtosis, a summary statistic that measures the peakedness of a distribution. Higher kurtosis is generally taken as evidence of greater friction in the policy process that produced the given change distribution.

\section{Policymaking in authoritarian regimes}

To date, Lam and Chan (2015) and Chan and Zhao (2016) have conducted the only tests of PET in the context of non-democracies (see also Pauw 2007 on South Africa; other tests have been in western democracies). Looking at the case of Hong Kong, Lam and Chan propose that non- 
democracies are characterized by less friction than democracies because the institutional design of these regimes centralizes power at the highest level of government, and yet, at the same time, the absence of these friction-including institutions also reduces external interferences to political processes. According to them, in the absence of electoral and participative mechanisms that are characteristic of democratic governments, officials lack the same incentives to monitor and respond to the external environment. Within such a system, Lam and Chan argue, under-response or stasis is extended; changes are reduced to prolong stability through mechanisms of negative feedback. However, the authors predict that pressure for change can build up to dangerous levels, especially when it reaches levels high enough to threaten the authority of the regime. The result of the two dynamics is a highly punctuated policy process 'in which the policymaking process is too insulated to react until the built-up pressures can no longer be resisted. But once it happens, the policy response can be radical and extremely forceful' (Lam and Chan 2015: 552). Chan and Zhao (2016) continue this inquiry, drawing on evidence from the People's Republic of China. They find that informational restrictions are the main drivers of punctuated equilibrium, and also that there is a negative correlation between the level of punctuation across Chinese regions and the level of labour disputes - a proxy for regime threat. In other words, Chinese policymakers face informational disadvantages when compared to their democratic counterparts, but they become more responsive to signals from society when the regime's existence is threatened.

Of course, much scholarly attention outside of the PET framework has been dedicated to non-democratic governance and these studies help form our hypotheses. In non-democratic systems, without free and fair elections, the durability of the ruling élite is threatened only when problems have grown to such an extent that unrest, either within the regime or society at large, appears imminent. This erodes the informational capacity of authoritarian governments on two 
fronts. ${ }^{2}$ First, it creates fewer incentives for leaders to seek out information. Indeed, structures that facilitate the flow of information in democracies, such as freedoms of speech and press, are often missing in authoritarian regimes and information is frequently censored or manipulated in favour of the regime. Although popular pictures of non-democracies might include elaborate mechanisms for observing the lives of citizens - from the Stasi's data-collection architecture in the German Democratic Republic to the Kremlin's heavy reliance on polling (Petrov, Lipman and Hale 2014) - the efficacy of such projects is fundamentally limited. ${ }^{3}$ Schedler (2013:37) writes of the 'structural opacity of authoritarian regimes' - that is, the informational uncertainty generated by, among other things, the incentives for citizens not to reveal their sincere preferences for fear of adverse responses from the regime. Second, whatever information is received by policymakers can more easily be ignored - in the short-run, at least. Moreover, even when there is a desire to respond, the necessary bureaucratic capacity may be lacking, as many of the civil institutions through which democracies implement their policies are missing in nondemocratic societies (Tsebelis [2002]). In particular, democracies may be better at delegation, whereby numerous semi-autonomous bureaucrats work together to promote the social welfare; a level of cooperation that is often impossible for highly centralized regimes.

Another set of institutional features of democracies and authoritarian systems works potentially in another way. The autocrat controls the levers of government; the democratic leader

\footnotetext{
${ }^{2}$ Recent literature on information in non-democracies has focused on authoritarian élites' proclivity for opacity, with measures of regime transparency drawing on the extent of fiscal information disclosure (see Boix and Svolik [2013]; Hollyer, Rosendorff and Vreeland [2011]; Wehner and Renzio [2013]). In other words, the existing literature has looked predominately at data dissemination, rather than information collection.

${ }^{3}$ To be sure, all regimes - regardless of electoral conditions - are interested in monitoring societal conditions, as well as the opinions of its citizens. Moreover, all attempts to collect and analyse data are hampered by doubts about whether reports by subjects reflect sincere attitudes. However, there are good reasons to believe that non-democratic regimes face particularly acute epistemic limitations.
} 
may have to negotiate more compromises. So, whereas democratic leaders may get more signals and be more aware of changing social demands or trends, they may not have the capacity unilaterally to respond. An independent legislature, a judicial body, or members of rival parties sharing control of a coalition government may refuse to cooperate; in sum, a democratic regime typically has some institutional barriers to action, and these are usually much greater than what would exist in an autocracy. ${ }^{4}$ To be sure, autocrats are not entirely free from institutional constraints, including intra-élite constraints (Roeder [1993]; Tsebelis [2002]). Our argument is simply that these constraints should be less than what is typically associated with democracies. Furthermore, many autocrats are likely to have grander ambitions than preventing civil unrest and may therefore be responsive to information under certain conditions. For example, autocrats sometimes create nominally democratic institutions in order to gather information, placate the opposition, or share power (for reviews, see Art [2012]; Brancati [2014]; Gandhi and Lust-Okar [2009]; Magaloni and Kricheli [2010]; Morse [2012]; and Pepinsky [2014]). Authoritarian regimes may therefore combine information search with the institutional freedom to act rapidly in order to solve developing social problems, thus greatly reducing overall levels of friction.

\section{Hypotheses}

We propose two competing hypothesis. The first is the 'informational advantage' hypothesis. ${ }^{5}$ Every government has a certain threshold of institutional response. Below the threshold policymakers ignore problems; above the threshold they attempt to solve them. Non-democracies

\footnotetext{
${ }^{4}$ Existing PET scholarship shows how much these institutional barriers matter when it comes to policy punctuations. Studies show that kurtosis is substantially higher for outcomes produced at latter stages of the policy process, where the cumulative effect of institutional friction is greatest (Baumgartner etl.al. [2009]; Jones and Baumgartner [2005]).

${ }^{5}$ Chan and Zhang (2016) make the same point, but write of 'the information disadvantage of authoritarianism', rather than the informational advantage of democracies.
} 
have fewer reliable mechanisms to gather information about societal problems, so the response threshold may be higher than in democracies. Policymakers in authoritarian regimes can ignore problems to the point at which social discontent threatens regime stability. In democracies, problems can be safely ignored only until representatives worry that their constituents will vote them out of office. Voting is much less costly than revolt, so in general we can expect democracies to be more responsive to information. ${ }^{6}$ Thus, we hypothesize:

Public budgeting in democracies will show lower levels of kurtosis than other political regimes.

The counter hypothesis is that any information gains provided by democratic institutions are outweighed by the frictions that accompany such institutions. This is the 'institutional efficiency' hypothesis, which suggests that authoritarian leaders may be better situated to act to resolve social issues than their democratic counterparts The institutional efficiency hypothesis thus states:

Public budgeting in autocracies will show lower levels of kurtosis than other political regimes.

Established PET studies seem to provide support to the institutional efficiency hypothesis. There is ample evidence, both within (Jones et al 2003) and across countries (Baumgartner et al 2009), that centralised institutions reduce decision-making costs resulting in less punctuated patterns of policy change. Existing comparative research, however, is mostly focused on democratic regimes. As such, it did not take into account significant variation in another key variable: censoring of information versus leaving it free and open. The existence of

\footnotetext{
${ }^{6}$ An alternative specification of the theory, with identical empirical expectations, would be as follows: In any complex system of government, decision-makers under-respond to information signals from their environment that are below some threshold of urgency. Above that threshold, where their attention is focused, they over-respond. The result of this under- and over-response to signals based on their intensity generates a punctuated-equilibrium pattern of high stability in most policy domains most of the time (e.g. hyper-incrementalism) and large changes in a few domains where the signal suggests a possible crisis or need to "catch up." As democratic regimes have an informational advantage (meaning they receive more signals), the degree of kurtosis there will be lower.
} 
widely dispersed sources of information typical of democracies generates a greater ability to respond (Baumgartner and Jones 2015), and stronger incentives to do so. We can expect the informational advantage of democracy to be greater than the decision-making advantage of authoritarianism. Indeed, many of the elements of governance often portrayed as impediments to efficient decision-making in multiparty democracies featuring separation of powers or the need to placate multiple veto-players actually serve to bring in greater amounts of information to the system. Thus, we expect our empirical tests to show greater levels of efficiency in democracies compared to authoritarian regimes.

We acknowledge that classifying regimes in a binary fashion - as either democratic or authoritarian - can be problematic, given the variety that this masks. In addition, and more broadly, any regime classification exercise is complicated by the persistent disagreements amongst scholars about typologies, measures, and relevant data. Our claim is only that the political freedoms and institutional structures typical of democratic governance affect patterns of budgetary change systematically. Drawing simple distinctions between regimes that are more or less democratic should be sufficient to capture these systematic differences. Building on this foundation, further research could undertake a nuanced exploration of how specific structures across regimes affect public budgets.

\section{Budget Data}

Previous scholarship has focused almost exclusively on Western democracies because these countries make longitudinal data readily available. Using original source documents, we introduce four new datasets: public budgets in Russia from 1998 to 2014, Turkey from 1970 to 
2004, Brazil from 1964 to 2010, and Malta from 1827 to 1936 and from 2001 to 2011. ${ }^{7}$ These

budget series are significant in that they span periods of authoritarian and democratic rule, allowing a unique test of PET theory. The focus on Russia, Turkey, Brazil, and Malta is governed principally by data availability; our empirical approach requires budgetary records that cover a regime transition and exist over a sufficiently long period of time to draw statistically meaningful distributions. Few countries fit these requirements and to our knowledge the data we assemble here is the most comprehensive in this regard (excluding the budget data from Hong Kong that has already been tested by Lam and Chan and data from China that was tested by Chan and Zang). The analysis gains from the dissimilarities - both geographic and political between the four countries by allowing a test of the hypotheses under a variety of socio-political circumstances. Table 1 provides a summary of the data. ${ }^{8}$

(Table 1)

Note that for Russia, Brazil, and Malta, inconsistencies in the reporting and management of public records preclude the use of uninterrupted time series. Another limitation is that budget authority is unavailable for Malta; we use annual expenditures instead. Budget authority measures the amount of authorized spending, rather than the amount that was actually spent in a given year, and is therefore a better measure of governmental decision-making. However, budget authority is often unavailable and scholars have substituted it with expenditures. This does not

\footnotetext{
${ }^{7}$ These dates correspond to calendar years of budget law passage, rather than fiscal years for planned budget spending. In the US, the Office of Management and Budget categorizes government expenditures into broad functional and more detailed subfunctional categories. The data for Russia, Turkey, Brazil, and Malta is grouped into categories that are roughly analogous to the US subfunctions; that is, the categories relate to relatively specific programmatic areas. For example, in Malta there are categories dedicated to 'care of the elderly' and 'airport development'. The appendix includes more details about data sources and composition.

${ }^{8}$ The number of observations reported in Table 1 relate to the number of spending category figures available, whereas the number of observations reported in later tables relate to percentage change figures.
} 
appear to have a meaningful effect on findings: when both budget authority and expenditures are available distributional analysis has revealed similar levels of kurtosis across these measures.

We also proceed with some caution as to the reliability of the budgetary record during periods of authoritarian government. Authoritarian regimes are known to repress or alter information, which may compromise the integrity of any budget data that is made public. A symptom of this is inconsistency in the use of budget categories during the authoritarian periods (although we find that such reclassifications are also relatively common during periods of democratic rule). Categories are often redefined from one year to the next, which limits our ability to assess longitudinal changes in budgetary priorities. This is more problematic in Russia and Brazil in particular, where our data covers lengthy periods of authoritarian rule, and less so for Turkey, which sees only relatively brief military interventions during our period of study, and Malta where the British kept accurate accounting records, known as 'Colonial Blue Books'. We do not claim that the data we assemble for the authoritarian periods is complete in the sense that it records every allocation made by these regimes; rather, only that it is the most complete account that can be compiled from public records. That being said, we have no reason to believe that authoritarian regimes systematically repress either very small or very large allocations; censorship should be neutral with respect to the shape of budget distributions, although this claim should be tested in future work. ${ }^{9}$ We are also careful to only include those budget categories which are consistently defined between two years; that is, we exclude to the best of

\footnotetext{
${ }^{9}$ One possibility that cannot be discounted with the data currently available is that authoritarian regimes hide major shifts in spending (either increases or cuts) by repressing budgetary records for the year in question. As Table 1 makes clear, there are gaps in our times series. If anything, it seems more plausible that regime elites would be more likely to censor unpopular major shifts than incremental spending changes, although we have no evidence to back up this assumption. As a result, even if these same elites were to publicize popular major shifts in expenditures, the exclusion of unpopular large shifts would work against our expectations regarding the level of kurtosis. Put differently, it is plausible to assume that observed kurtosis levels would be even higher in authoritarian regimes if we were to include currently unavailable data.
} 
our ability from the analyses any budget changes which might reflect a shift in the definition of the stated budget category rather than a substantive reallocation. ${ }^{10}$ Crucially, then, the changes we report below are real, not artefacts of shifting category definitions. (See the online appendix for explanations of the data sources used as well as descriptions of the budgeting process over time for the four country cases.)

\section{Results}

Freedom House attempts to quantify the political rights and civil liberties citizens enjoy. Based on these composite elements, Freedom House assigns countries a rank of 'Worst of the Worst', 'Not Free', 'Partly Free', or 'Free'. These aggregate scores are available annually from 1972 to 2014 and the first step in our analysis is to assign each year of budgetary data its corresponding freedom score. For Brazil and Malta, budget data is available prior to 1972. Indeed, Maltese budgets are available as far back as 1827 . Our main analysis excludes any year where we cannot assign a Freedom House score, but in the appendix (available online) we use the full time series when dividing the data based on regime transitions. For example, Malta transitioned from colonial rule to a period of colonial self-government in 1922 . We find that results are highly consistent.

Having assigned Freedom House scores, we then calculate annual percent change values for each spending category. As discussed, there is some inconsistency across budget categories. If a category had a change in its substantive definition in a certain year or was not reported, we do not calculate a percent change value for that year in that category. We also take a new approach to accounting for inflation. The data spans years of political and economic turmoil;

\footnotetext{
${ }^{10}$ Another option would be to aggregate upward by combining smaller programmatic areas of the budget into broad categories such as defense, social welfare, and agriculture. We found, however, that this leaves too few observations of budgetary change to draw reliable distributions.
} 
each country introduced at least one new currency or experienced a significant currency revaluation during our period of study. This makes inflation adjustments difficult and in many cases there is no consensus within the scholarly community about how such adjustments should be made. ${ }^{11}$ Rather than adjusting for inflation prior to calculating percent changes (the standard approach in the literature), we calculate changes relative to total government growth in that year. For example, if a budget category saw an annual increase of 10 percent and the total budget for that year grew by 7 percent, we consider that a 3 percent increase for that category in that year. If instead the budget category saw a 10 percent decrease, then that would be counted as a 17 decrease after factoring in overall budget growth. While atypical, this approach is both necessary given the historical context of our study and most importantly it preserves the essential element of the analysis, which is to assess how governments reprioritize problems. Crucially, it has no practical effect on the shape of the budget change distributions, which is our concern. It simply centres the change on an annual value of zero percent growth, whereas in fact the average growth could have been higher. As our concern is whether the shape is close to Normal or has high kurtosis, shifting the mean in this manner is not a concern. And it comes with the substantial advantage of allowing us to compare cases with wildly divergent currency values and inflation rates.

We pool percentage change values into distributions for each country and each Freedom House score. The histogram bars simply represent the number of cases in which a given budget was changed by $x$ percent, compared to its value in the previous year and the rate of overall government growth. Table 2 summarizes the results and Figure 1 presents the corresponding

\footnotetext{
${ }^{11}$ The exception is Brazil, where there is an agreed upon 'roadmap' for adjusting historic currency values for inflation. For Brazil, we therefore calculate percentage changes using inflation adjusted amounts; the standard practice. Results for Brazil are robust to these specification issues.
} 
distributions. Budgeting in each country follows a punctuated equilibrium pattern, with a tall central peak (indicating the predominance of incremental changes) and very wide tails (indicative of dramatic spending changes). This pattern is especially pronounced in Turkey during the 'Partly Free' period and least pronounced in Brazil during the 'Free' period, where the budget distributions come closest to the Normal. L-kurtosis is a standardized version of kurtosis that is robust against the disproportionate effects of outlying values. A Normal distribution has an L-kurtosis of 0.123, with higher values indicating greater leptokurtosis. Looking at the Lkurtosis values in Table 1 confirms the visual evidence from the figures: budgeting is leptokurtic.

(Table 2)

(Figure 1)

Evidence supports the information hypothesis rather than the institutional hypothesis in all three cases. In each country the transition toward greater freedom (and a more open system of government) corresponds with a drop in L-kurtosis, indicating a lower magnitude of punctuation during these periods. While the differences in L-kurtosis are only modest, they all point in the same direction. Furthermore, these findings are consistent with evidence presented by Lam and Chan (2015) that L-kurtosis is lower during periods of democratic governance. Collectively the results are compelling and suggest that democratic structures provide a powerful informational advantage, which conditions the policymaking process. ${ }^{12}$ Note, however, that greater freedom is not so important as to outweigh other inter-country differences. For example, the budget distribution during the 'Not Free' period in Russia is still closer to the normal than the

\footnotetext{
12 The appendix replicates these findings for Brazil and Turkey after excluding periods of economic turmoil from the data. (For Russia, periods of economic upheaval are an approximate match to the periods of missing data.) A concern would be if budgetary instabilities correspond with economic distributions and that in turn these disruptions are more likely during authoritarian governance. We find that excluding these potentially problematic years does not substantively change the results.
} 
distribution for the 'Free' period in Turkey. Political freedoms are important, but we still have a long way to go in explaining budgetary patterns across countries.

\section{Colonial and independent Malta}

Malta was part of the British Empire from 1826 until 1964 and because the British kept detailed management records of all their colonies, it is possible to assemble budget data for Malta during almost the entire colonial period. This is what we do. We assembled the dataset referencing the original colonial 'Blue Books' for the period 1827-1936. To our knowledge this is the first test of PET in a colonial setting. It also provides a further test of our hypotheses. Malta was granted home-rule by the British in 1921, so while still a colony, this marked an important transition toward a more open and participatory form of government. We can therefore divide the colonial era into two periods, with the expectation that political freedoms should be greater during the period when the Maltese people could run their own government. Finally, we complement our analysis of the colonial period with recent data covering the decade 2001-2011 that we obtained from Malta's National Statistics Office. We can thus compare colonial with independent Malta, a fully free country - and for most of the time covered, also a member of the European Union. In this way, we can replicate the study of the effect of transition to full democracy on the case of Malta. Figure 2 shows change distributions for these three periods. ${ }^{13}$

(Figure 2)

During the period of British rule, the L-kurtosis associated with the distribution is 0.652 , but when the Maltese gain greater autonomy through the transition to home rule L-kurtosis is

\footnotetext{
${ }^{13}$ For Malta, kurtosis scores associated with the democratic period are highly sensitive to the inclusion of small expenditure values. This is always a concern when estimating the kurtosis of percent change distributions. It is easier for policymakers to make a large change to a small base value, but these instabilities are less reflective of true policy punctuations than random fluctuations around a small number. Frequently analysts will address this problem by excluding small base values and this is what we do here, dropping expenditures less than $\$ 1$ million euros from the Malta analysis. Similar diagnostics are conducted for each country, but in these cases kurtosis scores are robust to this issue.
} 
0.569. L-kurtosis is even lower (0.499) during the 2001-2011 period, after full consolidation following independence and transition to democracy. ${ }^{14}$ This continues the trend established by the previous analysis. As governments transition toward greater freedom, their budgetary processes gain stability. Gains in informational capacity provided for by democratic structures seem clearly to outweigh any institutional efficiency afforded by authoritarian government. Our information hypothesis is confirmed and we can reject the efficiency hypothesis.

\section{Conclusion}

A robust literature has now explored PE theory with regard to budgeting, but that literature has almost exclusively been focused on advanced industrial democracies, with some attention to subnational budgets (e.g., states, municipalities, and school districts) within these nations. Here we present just the second example of detailed attention to the shape of budgetary change in nondemocratic settings, building on the work of Lam and Chan (2015) and Chan and Zhao (2016). This focus has revealed systematic differences in the way that democracies and non-democracies process and respond to information. Studies of Western governments have taken findings of budgetary punctuations as evidence for the disproportionate processing of information by policymakers and we find that these punctuations are even more pronounced in the context of non-democracy. This suggest that when it comes to information processing and response, democratic governance has an advantage over more authoritarian forms.

We hope to expand on the analysis presented above, which must first start with more data collection in non-democratic systems, as well as exploring the various mechanisms democratic and authoritarian regimes use to gather information and act on it. In particular, as we collect

\footnotetext{
14 That the data are unbalanced in the sense that there is sometimes more data for the non-democratic periods (Russia, Brazil, and Malta) and sometimes more for the democratic periods (Turkey) should not affect the results. There are sufficient observations in each period to draw statistically meaningful distributions and thus any systematic differences in budgetary behaviour should reveal themselves.
} 
more data from different types of regimes, it may be possible to pinpoint particular institutions or civil rights that affect the informational capacity of governments, and subsequently their decision-making processes. In addition, we hope to collect more nuanced data on other variables of interest - particularly economic instability - in order to exclude alternative explanations for distribution differences across regime types. We also note that there is great inter-state variation in the shape of budgetary change distribution - variation that a focus on political regimes appears insufficient in explaining. Ultimately we would hope to gain a better understanding of all factors - political, social, or economic - that affect the stability of government agendas. 


\section{References}

Alston, Lee J., Marcus André Melo, Bernardo Mueller and Carlos Pereira (2006) Political Institutions, Policymaking Processes and Policy Outcomes in Brazil. IDB Publications 39698, Inter-American Development Bank.

Art, D. (2012) 'What do we know about authoritarianism after ten years?', Comparative Politics 44(3): 351-73.

Baumgartner, Frank R., and Bryan D. Jones. (1993) Agendas and Instability in American Politics, Chicago: University of Chicago Press.

Baumgartner, Frank R. and Bryan D. Jones (2014) The Politics of Information, Chicago: University of Chicago Press.

Baumgartner, Frank R., Christian Breunig, Christoffer Green-Pedersen, Bryan D. Jones, Peter B. Mortensen, Michiel Neytemans, and Stefaan Walgrave. (2009) 'Punctuated Equilibrium in Comparative Perspective’, American Journal of Political Science 53 (3): 602-19.

Boix, C., and M. Svolik. (2013) 'The foundations of limited authoritarian government: Institutions, commitment, and power-sharing in dictatorships', The Journal of Politics 75(2): 300-16.

Brady, David W., and Craig Volden. 1998. Revolving Gridlock: Politics and Policy from Carter to Clinton. Boulder: Westview.

Brancati, Dawn. (2014) 'Democratic Authoritarianism: Origins and Effects', Annual Review of Political Science 17: 313-26.

Breunig, Christian and Chris Koski. (2006) 'Punctuated Equilibria and Budgets in the American States’, Policy Studies Journal 34: 363-79.

Breunig, Christian, Koski, Chris, and Peter B. Mortensen. (2010) 'Stability and Punctuations in Public Spending: a Comparative Study of Budget Functions', Journal of Public Administration Research and Theory 20 (3): 703-22.

Brown, D. (2002) 'Democracy, authoritarianism and education financing in Brazil'. Journal of Latin American Studies, 43, 115-141.

Chan, Kwan Nok, and Shuang Zhao. (2016) 'Punctuated equilibrium and the information disadvantage of authoritarianism: Evidence from the People's Republic of China', Policy Studies Journal DOI: 10.111/psj.12138.

Cooper, J. (2007). 'Military expenditure in the three-year federal budget of the Russian Federation, 2008-10', available at http://kms2.isn.ethz.ch/serviceengine/Files/ESDP/96405/ipublicationdocument_singledoc 
ument/be712761-0db9-4536-ba5e-

49cde3c19695/en/2007_10_cooper20071010\%5B1\%5D.pdf (accessed 20 November 2016).

Gandhi, J., and E. Lust-Okar. (2009) 'Elections under authoritarianism', Annual Review of Political Science 12: 403-22.

Hollyer, J., B. Rosendorff, and J. Vreeland. (2011) 'Democracy and transparency', The Journal of Politics 73(4): 1191-1205.

Jones, Bryan D., Tracy Sulkin, and Heather A. Larsen. (2003) 'Policy Punctuations in American Political Institutions', The American Political Science Review 97(1): 151-69.

Jones, Bryan D. and Frank R. Baumgartner. (2005) The Politics of Attention: How Government Prioritizes Problems, Chicago, IL: University of Chicago Press.

Jones, Bryan D., Frank R. Baumgartner, Christian Breunig, Christopher Wlezien, Stuart Soroka, Martial Foucault, Abel François, Christoffer Green-Pedersen, Chris Koski, Peter John, Peter B. Mortensen, Frédéric Varone, and Stefaan Walgrave. (2009) 'A General Empirical Law of Public Budgets: A Comparative Analysis', American Journal of Political Science 53: 855-73.

Lam, Wai Fung and Kwan Nok Chan. (2015) 'How Authoritarianism Intensifies Punctuated Equilibrium: The Dynamics of Policy Attention in Hong Kong', Governance, 28(4): 54970.

Magaloni, B., and R. Kricheli. (2010) 'Political order and one-party rule', Annual Review of Political Science 13: 123-43.

Mayhew, D. (1974) Congress: The electoral connection, New Haven, CT: Yale University Press.

Morse, Y. 2012. 'The Era of Electoral Authoritarianism.' World Politics, 64(1): $161-98$.

Padgett, John F. (1980) 'Bounded Rationality in Budgetary Research', American Political Science Review 74(2): 354-72.

Pauw, J.C. 2007. A measurement of year-on-year variation in the allocations to national departments in South Africa (2003/4-2007/8) from a public management point of view. Politeia 26, 3: 252-272.

Pepinsky, T. 2014. 'The institutional turn in comparative authoritarianism', British Journal of Political Science 44(3): 631-53.

Petrov, N., M. Lipman, and H. Hale. (2013) 'Three dilemmas of hybrid regime governance: 
Russia from Putin to Putin', Post-Soviet Affairs 30(1): 1-26.

Robinson, Scott E., Carla M. Flink, and Chad M. King. (2014) 'Organizational History and Budgetary Punctuation', Journal of Public Administration Research and Theory 24: 45971.

Roeder, P. (1993) Red Sunset: The Failure of Soviet Politics, Princeton, New Jersey: Princeton University Press.

Schedler, A. (2013) The politics of uncertainty: Sustaining and subverting electoral Authoritarianism, New York, NY: Oxford University Press.

Thurber, James A., and Antoine Yoshinaka. 2015. American Gridlock: The Sources, Character, and Impact of Political Polarization. New York: Cambridge University Press.

Tsebelis, G. (2002) Veto Players: How Political Institutions Work, Princeton, New Jersey: Princeton University Press.

Wehner, J., and P. Renzio. (2013) 'Citizens, legislators, and executive disclosure: The political determinants of fiscal transparency’, World Development 41: 96-108.

Wildavsky, Aaron. (1964) The Politics of the Budgetary Process, Boston, MA: Little Brown. 


\section{Tables}

Table 1. Data characteristics.

\begin{tabular}{lrrr}
\hline Country & Time Period & $\mathrm{N}$ & Budget Type \\
\hline Russia & $1998-2003 ; 2004-2006 ; 2010-2014$ & 1,260 & Budget Authority \\
Turkey & $1970-2004$ & 1,046 & Budget Authority \\
Brazil & $1964-1985 ; 1995-2010$ & 1,810 & Budget Authority \\
Malta & $1827-1937 ; 2001-2011$ & 3,074 & Expenditures \\
\hline
\end{tabular}

Table 2. Kurtosis by Freedom House rankings.

\begin{tabular}{lrrrr}
\hline Country & Time Period & $\mathrm{N}$ & Kurtosis & L-kurtosis \\
\hline Russia & & & & \\
Partly Free & $1998-2003$ & 435 & 74.21 & 0.446 \\
Not Free & $2004-2006 ; 2010-2014$ & 526 & 98.49 & 0.515 \\
\hline Turkey & & & & \\
Partly Free & $1970-1972 ; 1979-2004$ & 746 & 457.00 & 0.706 \\
Free & $1973-1978$ & 161 & 95.39 & 0.657 \\
\hline Brazil & & & & \\
Partly Free & $1972-1985 ; 1995-2001$ & 979 & 87.36 & 0.354 \\
Free & $2002-2010$ & 575 & 231.39 & 0.321 \\
\hline
\end{tabular}




\section{Figures}

Figure 1. Change distributions by Freedom House rankings.

A) Russia, Not Free.

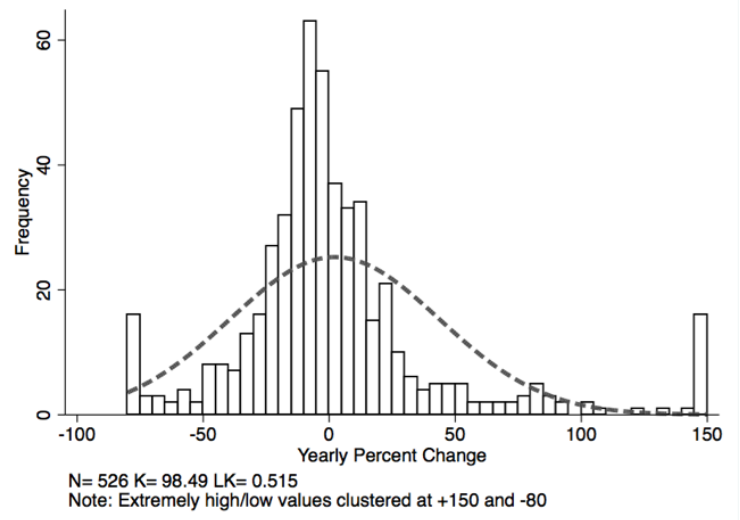

C) Turkey, Partly Free.

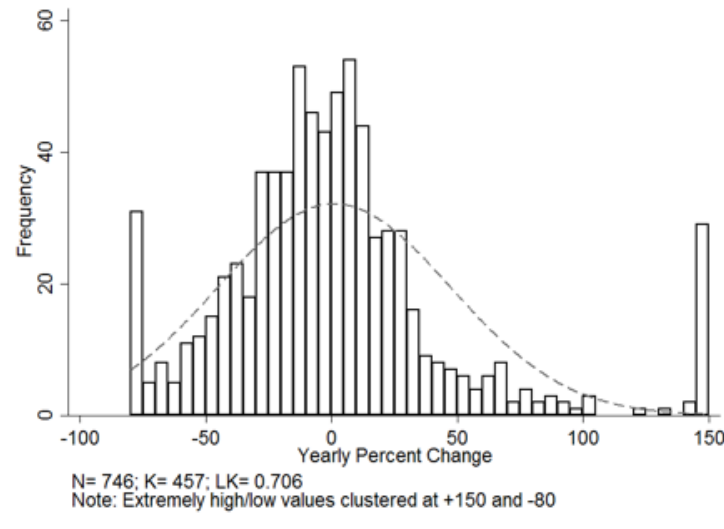

E) Brazil, Partly Free.

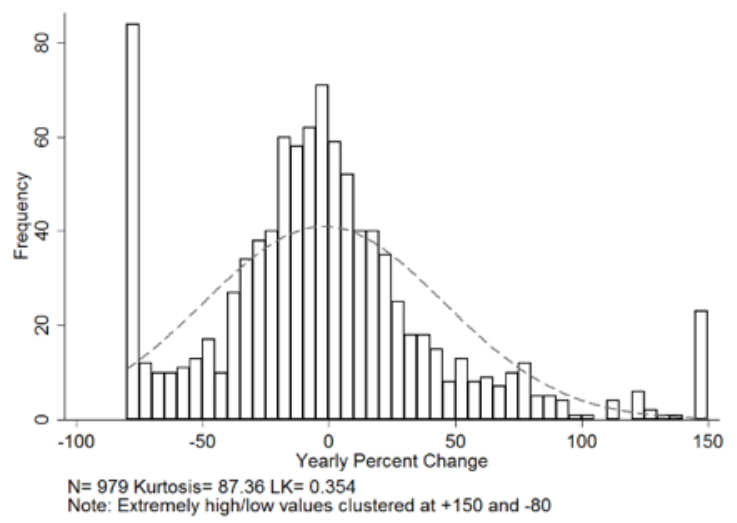

B) Russia, Partly Free.

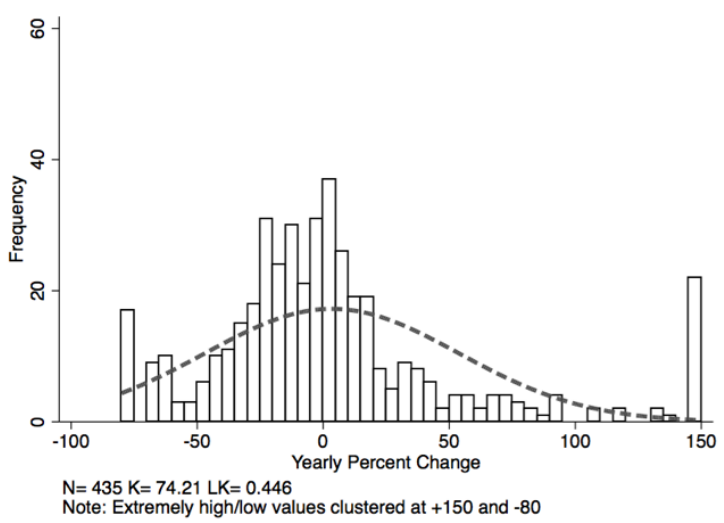

D) Turkey, Free.

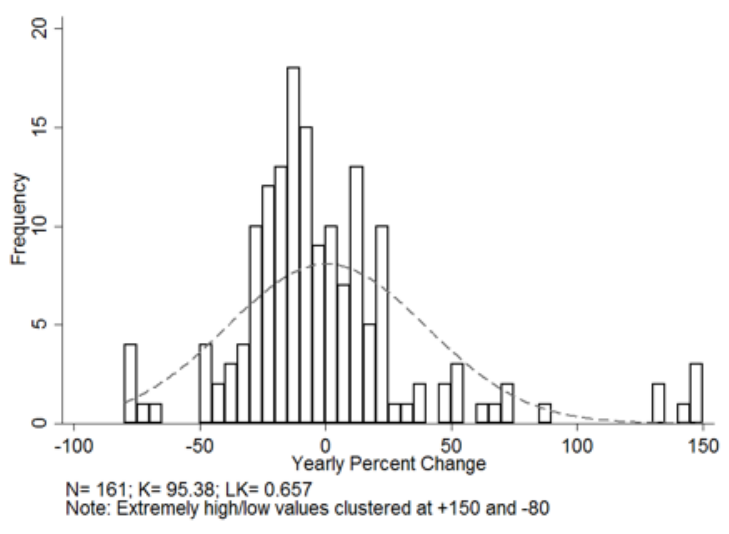

F) Brazil, Free.

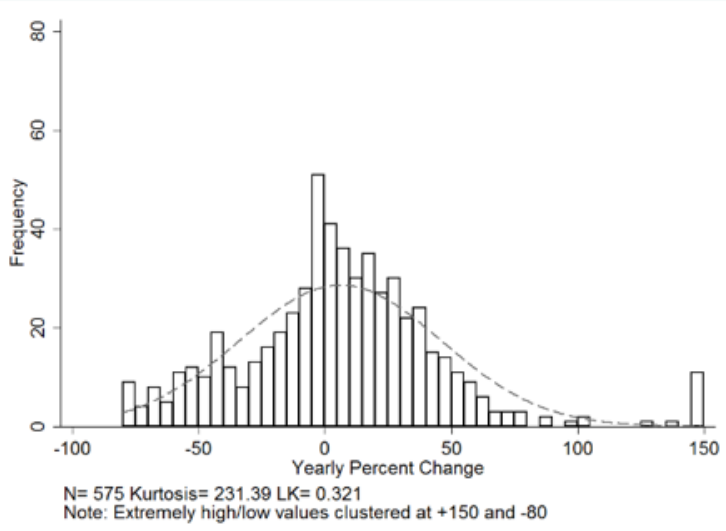


Figure 2. Colonial budgeting in Malta.

A) British rule.

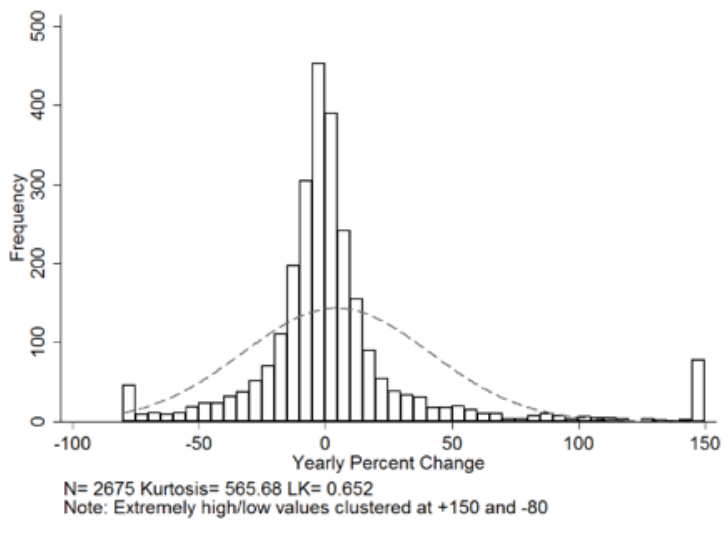

C) Independence, free.

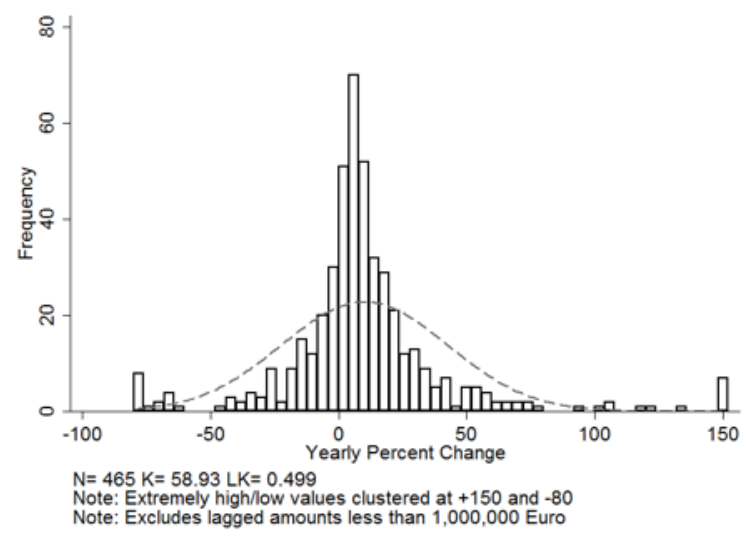

B) Self rule.

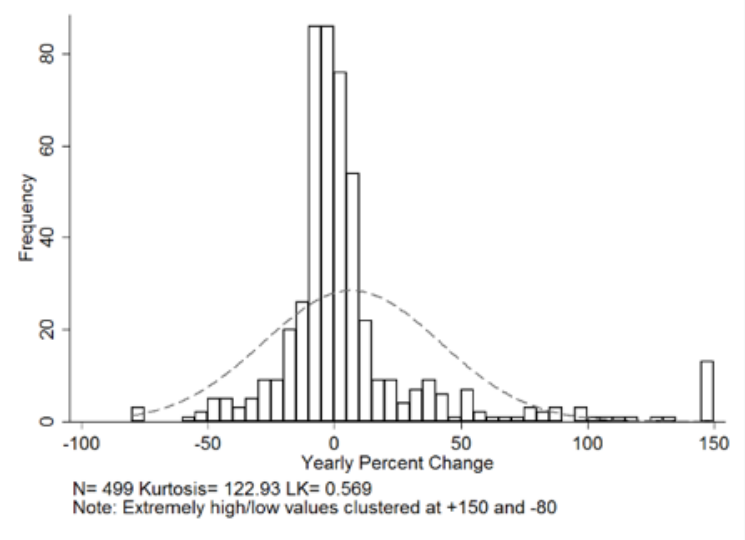




\section{Budgetary Change in Authoritarian and Democratic Regimes}

Frank R. Baumgartner, Marcello Carammia, Derek A. Epp, Ben Noble, Beatriz Rey, and Tevfik Murat Yildirim

Forthcoming, Journal of European Public Policy, 2017

\section{On-line Appendix}

\section{A. Data Sources and Descriptive Statistics}

\section{B. Robustness Tests}

\section{Descriptions of the Budgeting Process in Each Country}

For reasons of space, we have not included in the main print-version of our article detailed descriptions of our data sources, as well as how the budgetary process works in each of the countries studied. We provide that information here.

\section{A. Data Sources and Descriptive Statistics}

\section{Russia}

Russian spending figures are drawn from a variety of sources. In order to calculate changes in spending priorities over time, we need unamended, overall spending figures - that is, figures drawn from the original budget law for a particular year, and that cover both classified and unclassified spending. The relevant appendix (attached to budget laws) containing these figures is titled Raspredelenie raskhodov federal'nogo biudzheta po razdelam i podrazdelam funktsional'noi klassifikatsii raskhodov biudzhetov Rossiiskoi Federatsii (Distribution of expenditures of the federal budget by sections and subsections of the functional spending classification of budgets of the Russian Federation), ${ }^{15}$ which provides a breakdown of total spending (unclassified and classified combined) by functional spending category. These

\footnotetext{
${ }^{15}$ The wording varies slightly across years.
} 
appendices are available for the 1999 to 2007 budgets from the legal information portal Zakonodatel'stvo Rossii - an official resource curated by the Federal Protection Service (Federal'naia sluzhba okhrany). ${ }^{16}$ Beginning with the 2008 budget, however, this appendix has not been made public, with a draft version not introduced for open legislative consideration and the final version not released along with the budget law. As Cooper (2007: 2) argues, '[b]y dropping the usual appendix providing a functional breakdown of total budget expenditure, an unprecedented degree of classification of the budget has been achieved, in addition to the traditional practice of declaring some appendix secret'.

Fortunately, spending figures for the 2012 to 2015 budgets are included in the Federal Exchequer's (Federal'noe kaznacheistvo) quarterly reports on budget implementation. ${ }^{17} 2011$ budget spending figures are included in the Audit Chamber's (Schetnaia palata) report on the main supplementary budget bill. ${ }^{18}$ Although figures for 2009 are available from the same source, figures from 2008 and 2010 are not available, meaning it is not possible to calculate change statistics. Although these sources allow us to track diachronic spending shifts for a number of years in non-democratic Russia, it is not clear why these bodies are allowed to publish information which appears to be classified by the Government.

For the 1998-2014 period under examination, three different spending category classification systems were used: 1999-2004 (26-27 categories); 2005-2010 (11 categories); and 2011-2014 (14 categories). Beyond these changes, nine observations have been deleted due to concerns about the comparability of spending figures - that is, that the associated change statistics reflect changes in reporting practices rather than actual shifts in spending priorities.

\footnotetext{
${ }^{16}$ The website address is http://pravo.gov.ru.

${ }^{17}$ These reports are available here: http://www.roskazna.ru/ispolnenie-byudzhetov/federalnyj-byudzhet/.

${ }^{18}$ This bill's webpage - and the Audit Chamber's report - is available here: http://asozd2.duma.gov.ru/main.nsf/(Spravka)?OpenAgent\&RN=542807-5.
} 
Brazil

The dataset for Brazil is comprised of the available authorized budget data reported by the IBGE from 1964 to 1985 and the authorized budget data reported in the Brazilian Budgetary Law (Lei Orçamentária Anual, LOA) from 1995 to 2010. The data have been converted into 2014 Reais $(\mathrm{R} \$)$ and are listed by topic codes that cover the executive, legislative, and judicial branches and their subtopics. The formulas for monetary and inflation adjustment were calculated based on the dates of approval of the LOAs. We rely on different sources of data because the Brazilian Institute of Geography and Statistics (IBGE) does not report the authorized budget, but the executed budget, from 2001 on. The IBGE and LOA data sets are nevertheless comparable, since both data sets report budget authority data.

We do not investigate public budgeting during the period in which Brazil was drafting its new constitution or the first years after democratization (1986 to 1994). The existing IBGE budget data for the period of 1986-1994 are not entirely reliable. For instance, Brown (2002) finds that the country's debt crisis led to accounting changes that render comparisons after 1987 very difficult. As indicated by our data set, this limitation is only circumvented with the establishment of the Real plan in 1994.

Altogether, the dataset has 105 different budget categories, which are all the categories reported in the IBGE and in the LOA data sets for both periods. The sum of budget categories reported for each year yields the total budget of each year. ${ }^{19}$ While 105 categories existed during the time period of our study, not all categories exist in each year. Rather, categories vary across and within political regimes because the Brazilian government altered them throughout the years.

\footnotetext{
${ }^{19}$ In order to calculate the total budget for each year, one needs to exclude the following categories: 10000 (Executive Branch), 30000 (Legislative Branch as reported in the authoritarian period) 30500 (Legislative Branch as reported in the democratic period), 50000 (Judicial Branch), and 90400 (Other expenses). These categories represent the sum of several subcategories, which are included separately and are therefore redundant.
} 
These modifications occur in the democratic period because the president has the power to create, modify or extinguish ministries, secretaries, and public administration bodies through special legislation. To illustrate, the budget category that represents the expenses of the Ministry of Agriculture takes on the following names in the data set: 'Ministério da Agricultura', 'Ministério da Agricultura, Abastecimento e Reforma Agrária', 'Ministério da Agricultura e do Abastecimento', 'Ministério da Agricultura, Pecuária e Abastecimento', and 'Ministério do Desenvolvimento Agrário'. These differences are not limited to nomenclature, but reflect substantive changes in the scope and purpose of the Ministry of Agriculture. As indicated previously, in our analysis we included only budget categories which are consistently defined between two years.

\section{Turkey}

Turkish budget data come from the General Directorate of Budget and Fiscal Control (BFC; Bütçe ve Mali Kontrol Müdürlüğü), a subunit of the Ministry of Finance in Turkey. Appendices for budget allocation decisions for the period of 1924-2005 have been made public (in English and Turkish) at the BFC's website. A larger body of data about fiscal policy, including the period of the Ottoman Empire, was published in multiple studies (Shaw and Shaw 1977) ${ }^{20}$.

The budget data available at the BFC's website provides a breakdown of total spending by spending category. This classification shows how much money is allocated to each spending unit (ministries and government organizations) for a fiscal year. These figures include data on 'allocated funding', 'actual spending' and 'budget share'. The number of spending units does not change much over time, with the range being 30-36. As is mentioned previously, we do not

\footnotetext{
${ }^{20}$ T., 2003. Osmanlı malî istatistikleri bütçeler, 1841-1918 (Vol. 7). TC Başbakanlık Devlet İstatistik Enstitüsü.
} 
calculate annual change statistic for inconsistent spending units that undertook organizational change.

There is no missing data in Turkish spending figures for the period under examination. Except some years in the late 1800s, allocated funds along with actual spending can be found at the BFC's website ${ }^{21}$ and in Güran (2003).

\section{Malta}

Maltese spending figures are drawn from two different sources. For a large part of the British colonial period (1813-1964), the British authorities published 'Blue books', which were recently digitalised and published online at:

https://nso.gov.mt/en/nso/Historical_Statistics/Malta_Blue_Books/Pages/Malta-Blue-

Books.aspx. Such books provided a wealth of information on such socio-economic aspects as population, currencies, trade and currencies, education and climate (but occasionally even description of botanic species or street maps). Spending figures were regularly included in the Blue books in a dedicated chapter on 'net revenue and expenditure', which we digitalised and put in spreadsheets. Blue books cover the period 1821-1937, with the only gaps in 1823 and 1826. Because the gaps were concentrated at the beginning of the time series, and also to avoid possible biases associated to the changeover between the old currency (scudo) and the 'new' one (pound sterling) that happened in 1826, we only used data starting from 1827. Expenditures data were recorded at a rather detailed level, and spending categories were relatively stable considering the long time covered. We counted 147 different categories that were used at least two consecutive times and were thus useful to calculate budget changes. Of these, 79 categories

\footnotetext{
${ }^{21} \mathrm{http} / / /$ www.bumko.gov.tr/?_Dil=2
} 
recurred at least ten times. Spending figures for 2001 to 2011 are available from the European Union's Classification of the Functions of Government (COFOG) dataset.

\section{B. Robustness Tests}

\section{Regime Classification}

Concerns about the effect of regime-classification variation on the results reported in the article motivate us to pursue various robustness tests. If results consistently point in the same direction after multiple replications, this should lend greater credibility to our conclusions, even if certain concerns about data quality remain. In the article, we use Freedom House scores to separate authoritarian and democratic regimes. This appendix replicates our analysis using three alternative classification systems: Polity IV, Varieties of Democracy, and Unified Democracy Scores.

Polity IV codes 'the authority characteristics of states in the world system for purposes of comparative, quantitative analysis' (Marshall, Gurr, and Jaggers 2013). Specifically, we use Polity IV codes corresponding to political competition. We have theorized that it is the electoral connection that provides leaders in democratic regimes with the incentive to seek out and engage with policy information, so it makes sense to look at political competition. Polity IV divides regimes into five levels of political competition: repressed, suppressed, factional, transitional, and competitive. Every year of available budget data for Russia corresponds with the 'transitional' period for political competition, offering no opportunity for comparison. Malta is not coded at all under Polity IV, so our replication looks at only Brazil and Turkey. Table A1 displays the kurtosis statistics corresponding to the distribution of changes associated with each level of political competition.

Table A1. Kurtosis by Polity IV (Political Competition).

\begin{tabular}{lllll}
\hline Country & Time Period & N & Kurtosis & L-kurtosis \\
\hline Turkey & & & &
\end{tabular}




\begin{tabular}{lrrrr} 
Factional & $1971-1972 ; 1979-1981 ; 1996-2004$ & 350 & 208.26 & 0.779 \\
Transitional & $1973-1978 ; 1983-1995$ & 531 & 91.14 & 0.440 \\
\hline Brazil & & & & \\
Repressed & $1966-1974$ & 264 & 10.90 & 0.651 \\
Suppressed & $1975-1985$ & 368 & 47.11 & 0.467 \\
Transitional & $1995-2010$ & 595 & 40.40 & 0.382 \\
\hline
\end{tabular}

For both Brazil and Turkey, L-kurtosis decreases substantially moving from periods of low to higher political competition. This provides additional support for the informational advantage hypothesis. Political competition forces leaders to engage with policy information, as an administration that is unresponsive to shifting environmental challenges will be voted out of office.

The new 'Varieties of Democracy' (V-Dem) classification system offers measures of five principles of democracy (electoral, liberal, participatory, deliberative, and egalitarian) and these are disaggregated into a variety of variables measuring such things as judicial independence, electoral regularity, and gender equality (Coppedge et.al. 2015b). From the V-Dem databank, we use a composite variable called the electoral democracy index, which captures Robert Dahl's institutions of polyarchy: freedom of association, suffrage, clean elections, elected executive, and freedom of expression (Coppedge et.al. 2015b). Countries can receive scores of either 0, 0.25, $0.5,0.75$, or 1 , with higher scores indicating greater electoral accountability. The V-Dem codebook (Coppedge et.al. 2015a) suggests that the scores can be associated with 'closed autocratic,' 'autocratic,' 'ambivalent,' 'minimally democratic,' and 'democratic' regimes. Table A2 shows the results of the distributional analyses using V-Dem's electoral democracy index to divide the data. If there are fewer than 100 observation associated with an electoral democracy score, that period is not included in the analysis over concerns about the reliability of distributions drawn from small datasets. (Malta is not rated by the V-Dem system and therefore not included in the table.) 
Table A2. Kurtosis by Varieties of Democracy scores.

\begin{tabular}{lrrrr}
\hline Country & Time Period & N & Kurtosis & L-kurtosis \\
\hline Turkey & & & & \\
Ambivalent & $1984-1989$ & 155 & 49.16 & 0.441 \\
Minimally Democratic & $1971-1979 ; 1990-2004$ & 624 & 366.89 & 0.735 \\
\hline Brazil & & & & \\
Autocratic & $1965-1985$ & 668 & 30.36 & 0.853 \\
Democratic & $1995-2010$ & 595 & 40.40 & 0.382 \\
\hline Russia & & & & \\
Ambivalent & $1998-2002$ & 343 & 74.81 & 0.433 \\
Autocratic & $2002-2003 ; 2004-2006 ; 2010-2012$ & 438 & 37.70 & 0.497 \\
\hline
\end{tabular}

Results are mixed. Brazil shows a dramatic reduction in kurtosis moving from a more autocratic to a more democratic period; evidence supportive of the informational advantage hypothesis. For Russia, the results point in the same direction, but the magnitude of change is smaller. The results for Turkey are, in contrast, supportive of the institutional efficiency hypothesis: more democratic years are associated with higher L-kurtosis. V-Dem rates Turkey as 0.75, minimally democratic, throughout the 1970s, 1990s, and 2000s, during which the country experienced two military interventions. Freedom House distinguishes the late 1970s as a period of greater freedom and categorizes all other years as 'partly free'. So, there are considerable discrepancies in the way the V-Dem electoral democracy index and Freedom House classify Turkey and they affect the results of the distributional analysis.

Finally, we use Unified Democracy Scores (U-Dem), which are estimated using Bayesian statistical models to create a general scale of democracy based on thirteen measures of regime type (Pemstein, Meserve, and Melton 2010). The scale is continuous, ranging from -0.50 for the most autocratic regimes to 0.50 for the most democratic. We subdivide this continuous measure into four U-Dem quartiles so that we have enough observations in each quartile to draw change distributions. Table A3 shows the results of distributional analyses that group budgetary changes 
based on these quartiles. If there are fewer than 100 observations in a quartile we do not draw a distribution for that grouping of observations. 
Table A3. Kurtosis by Unified Democracy scores.

\begin{tabular}{lrrrr}
\hline Country & Time Period & $\mathrm{N}$ & Kurtosis & L-kurtosis \\
\hline Turkey & & & & \\
$1^{\text {st }}$ Quartile (Least Freedom) & $1973 ; 1983-2003$ & 594 & 580.00 & 0.664 \\
$3^{\text {rd }}$ Quartile & $1974-1979$ & 187 & 110.13 & 0.623 \\
\hline Brazil & & & & \\
$1^{\text {st }}$ Quartile (Least Freedom) & $1965-1974$ & 300 & 12.63 & 0.690 \\
$2^{\text {nd }}$ Quartile & $1975-1985$ & 368 & 47.11 & 0.467 \\
$4^{\text {th }}$ Quartile (Most Freedom) & $1995-2010$ & 595 & 40.40 & 0.382 \\
\hline Russia & & & & \\
$2^{\text {nd }}$ Quartile & & & \\
$3^{\text {rd }}$ Quartile & $2004-2005 ; 2011-2012$ & 265 & 38.37 & 0.520 \\
\hline
\end{tabular}

L-kurtosis estimates for Brazil, Russia and Turkey support the informational advantage hypothesis. In all three cases, L-kurtosis is lower during periods of greater political freedom, although for Russia and Turkey the differences are smaller in magnitude than the differences found in Brazil.

By using the various classification systems, we gain consistent measures of the democratic tendencies of different regimes over time. But the historical span of these systems is limited and for Malta we have budget data from much further back in time than regimeclassification data is available. Furthermore, there are always some concerns about the accuracy of generalized classification systems. For these reasons, we replicate our analysis using regime transitions as the dividing points in the data. That is, we simply look at the historical record and note (to the best of our ability) the points at which one regime fell and was replaced by another. Table A4 shows the results. 
Table A4. Kurtosis by regime.

\begin{tabular}{lrrrr}
\hline Country & Time Period & $\mathrm{N}$ & Kurtosis & L-kurtosis \\
\hline Russia & & & & \\
Democracy & $1998-2003$ & 435 & 74.21 & 0.446 \\
Authoritarian & 2004-2006; 2010-2014 & 526 & 98.49 & 0.515 \\
\hline Turkey & & & & \\
Democracy & & & \\
Military & $1970-1978 ; 1982-1995 ; 1997-2004$ & 484 & 454.37 & 0.736 \\
\hline Brazil & $1979-1981 ; 1996$ & 69 & 4.91 & 0.195 \\
Military & & & & \\
Democracy & $1964-1985$ & 944 & 80.70 & 0.376 \\
\hline Malta & $1995-2010$ & 866 & 229.78 & 0.283 \\
Colonial & & & & \\
Colonial Self-Rule & $1827-1921$ & 2,675 & 565.68 & 0.652 \\
Democracy & $1922-1936$ & 499 & 122.93 & 0.569 \\
& $2001-2011$ & 380 & 71.11 & 0.499 \\
\hline
\end{tabular}

Using the longer data series for Brazil and the different dividing points for each country does not substantively alter the results. (The exception is Turkey, where the low number of cases during periods of military rule create concerns about the robustness of distributional statistics.) For the most part, however, we still see a lower magnitude of punctuation during periods of greater political openness. Altogether, we have conducted sixteen tests of the hypotheses (across countries and classification systems) and twelve of these tests support the informational advantage hypothesis. So, while the results are not unequivocal, they point strongly in one direction and appear to reflect real differences in the abilities of democracies to process and act on information.

\section{Economic analysis}

Concerns about alternative explanations motivate us to engage in another robustness test. Brazil, Russia, and Turkey experienced economic instability during the periods analyzed in this paper. Thus, we need to account for the possibility that it is economic instability, and not difference in regime type, that explains the kurtosis patterns we observe. This issue is less problematic for Russia because the years of economic crisis are already excluded from our data set given our inability to compute spending change statistics for the 2008, 2009, and 2010 budgets. We rely on 
existing literature to define the years of economic collapse for the two other countries. For Turkey, we exclude the years of 1994 and 2001 (Celasun [1998]; Özatay and Sak [2002]; Akyüz and Boratav [2003]; Macovei [2009]; Öniş [2009]). For Brazil, we exclude the second period of the military regime (1975-1985), during which the country experienced oil shocks and debt crises; and the years of 1995, 1998, 1999, and 2001, during which the country was hit by different financial crises (Skidmore [1988]; Skidmore et al. [2010]; Toshniwal [2012]). Table A5 reports the results of this analysis using Freedom House scores: L-kurtosis still declines moving from partly free to free periods. In fact, results remain unaltered across multiple replications of this analysis using Polity IV, V-Dem, U-Dem scores and historical records.

Table A5. Kurtosis by Freedom House rankings (years of economic crisis excluded)

\begin{tabular}{lrrrr}
\hline Country & Time Period & N & Kurtosis & $\begin{array}{r}\text { L- } \\
\text { kurtosis }\end{array}$ \\
\hline $\begin{array}{l}\text { Brazil } \\
\text { Partly }\end{array}$ & $1975-1985 ; 1996-1997 ; 2000$ & 222 & 26.01 & 0.433 \\
$\begin{array}{l}\text { Free } \\
\text { Free }\end{array}$ & $2002-2010$ & 210 & 12.03 & 0.319 \\
\hline $\begin{array}{l}\text { Turkey } \\
\text { Partly }\end{array}$ & $1970-1972 ; 1979-1993 ; 1995-2000 ; 2002-2004$ & 718 & 439.80 & 0.710 \\
$\begin{array}{l}\text { Free } \\
\text { Free }\end{array}$ & $1973-1978$ & 161 & 95.38 & 0.657 \\
\hline
\end{tabular}

\section{Descriptions of the Budgeting Process in Each Country}

\section{Russia}

The political environment has varied considerably in post-Soviet Russia. Following the collapse of the Soviet Union, the country experienced an unprecedented level of political competition, media freedom, and economic liberty. However, the concomitant collapse in state capacity meant that President Yeltsin's tenure, 1991-1999, was also marked by economic turbulence, threats to the territorial integrity of the federation, and 'feckless pluralism' (Carothers 2002: 10) instead of consolidated multi-party politics. In response to this impression of disorder, Vladimir Putin set 
out on a project of re-establishing state control on his election to the presidency in 2000 - an aim aided greatly by the concurrent rise in world oil prices.

Although there are notable differences in how post-Soviet Russia's political system has been classified, there is a broad consensus of an authoritarian turn under the leadership of President Putin. Freedom House changed its classification of Russia from 'Partly Free' in 2003 to 'Not Free' in 2004, citing 'the virtual elimination of influential political opposition parties within the country and the further concentration of executive power' (Freedom House 2005). Along with executive dominance over the legislature - thanks to the rising seat share of the 'party of power', United Russia — the Putin administration clamped down on media freedom, removing most independent television news outlets. In addition, oligarchs with political pretensions - most notably Mikhail Khodorkovsky — were threatened into exile or imprisoned.

This narrative of increased executive control was also reflected in budgetary practices. Whereas budgets passed in the 1990s were subject to intense lobbying during legislative passage, often resulting in delayed promulgation and making the final laws un-implementable (Troxel 2003), budgeting in the 2000s became a much more orderly affair, with fewer channels for outside influence on executive tax and spending decisions. However, the rising dominance of the executive branch and apparent subsequent gains in institutional efficiency went hand-in-hand with the loss of information transparency. Beginning with the 2008 budget, complete spending figures broken down by functional sub-category have not been made public by the Russian Government - something that, according to Cooper (2007: 2), constitutes an 'unprecedented degree of classification [opacity] of the budget'. ${ }^{22}$ Beyond the markedly reduced influence of the

\footnotetext{
${ }^{22}$ As described in the appendix, spending figures for later years are taken from reports produced by other state bodies involved in the budget process, which - for unknown reasons - are able to make public ostensibly classified information.
} 
legislature in the decision-making process, increased opacity appears to be another way in which budgeting processes can differ between periods of democracy and non-democracy (see Wehner and Renzio 2013).

\section{Turkey}

The history of Turkish democracy can best be described by large fluctuations starting from the multiparty politics in 1950. Although the end of single-party political system was of great importance for the democratization of Turkish politics, the newly elected government under the leadership of Adnan Menderes soon embraced undemocratic practices to restrict opposition activities. As the deteriorating relations between government and opposition reached its nadir in 1960, the military intervened in politics for the first time since the establishment of the Republic (1923), removing the government party from office and executing its leaders. Shortly afterwards, in 1961, elections were held and Turkish politics entered into a new phase, one in which polarization and political violence increased dangerously to the point at which the military intervened in politics for the second time by delivering memoranda. However, violence and political instability continued to develop (Tachau and Heper 1983). In the following ten years, politics was mostly dominated by unstable coalitions and minority governments, resulting in right-wing/left-wing political violence. For the third time, in 1980, the military took control of the government and banned all the political activities temporarily until 1983. The influence of military on politics has been restricted only after late 2000s during the AKP's (Justice and Development Party) government.

Although Turkish politics faced three military interventions in two decades $(1960,1971$ and 1980), the role that the military played was categorized as 'moderator' and 'guardian' as these military regimes ended soon after the political authority was restored (Tachau and Heper 1983). Instead, the conditions that put Turkey among 'partly-free' countries emerged under civil 
governments. An electoral threshold of 10 percent that prevented certain parties from winning seats in parliament and bans on political activity of the Kurdish élite harmed political rights and civil liberties in Turkey during the 1990s. Moreover, freedom of expression had long been limited in Turkey; many journalists were accused of insulting state officials and imprisoned in 1999 (see Freedom House 1999; section on Turkey), which received much attention particularly from the EU and leading non-profit organizations.

The Turkey data covers the period of 1970 to 2004 . The first period, 1970-1972, is categorized as partly free; 1973-1978, free; and 1979-2004 again partly free. The latter period coincided with the rise of the Kurdish movement in the country: Turkey's treatment of its Kurdish citizens has been the main obstacle to the democratization of Turkish politics (Ergil 2000). There are good reasons to expect that certain political and social groups were isolated from the decision-making process and their demands were not taken into consideration during this period.

Brazil

Our analysis focuses on the years of authoritarian rule (1964-1985), and, in the democratic period, the years of centre party rule (PSDB, 1995-2002, during which the president was Fernando Henrique Cardoso) and the years of left party rule (Workers' Party, or the PT, 20032010, during which the president was Luiz Inácio Lula da Silva). The authoritarian years under the Brazilian military can be divided into two periods. The first (1964-1974) was characterized by the dominance of a hard-liner group of military officers, economic prosperity, and the relative absence of social unrest. The second (1975-1985) was characterized by the dominance of the moderate group of military officers, economic crisis, and presence of social unrest.

The first period of the military regime was marked by the severe restriction of political and civil rights. The government interfered in almost all labour unions and civil society 
organizations, strikes were banned and student movements were declared to be extinct. Political rights were also suspended. The government established indirect elections for presidents and governors. Only two political parties were allowed to exist: the ARENA (Aliança Renovadora Nacional), the regime party, and the MDB (Movimento Democrático Brasileiro), the opposition party. During this period, rulers temporarily shut down Congress in 1968 and edited the AI5 (Institutional Act 5), suspending all democratic rights and constitutional freedom.

During the second period of the military regime, Brazil's economy started to suffer the effects of the oil shock of 1973 combined with the maintenance of investments in unfavourable conditions. Although the government tried to contain the crisis, a second oil shock (1979) jeopardized its plan. The annual rate of inflation did not stop growing during this period, which did not stop the Brazilian military regime from focusing on economic growth at all costs (Skidmore 1988). President João Figueiredo, the last military ruler to occupy office, turned to the IMF (International Monetary Fund) for assistance (Baer 2014) in 1982. Ernesto Geisel, who took office in 1974, had committed his government to starting the process of political opening (Huntington 1991). Several sectors of society began to organize in this period (for instance, the 'Diretas Já' movement demanded direct presidential elections between 1983 and 1984), which increased the pressure for the government to promote institutional reforms (such as the end of the censorship of radio and television in 1978).

The transition to democracy occurred in March 1985 when President José Sarney took office after the death of Tancredo Neves, who had been indirectly elected president by an electoral college. Freedom House notes the transition, changing its classification of Brazil from 'Partly Free' to 'Free' in $1985 .^{23}$ These political changes also marked the beginning of a

\footnotetext{
${ }^{23}$ Freedom House ranks the country as Partly Free again from 1993-2002. Such classification is justified by increases in violence and lawlessness on the part of the police, upsurge of organized crime, lack of
} 
tumultuous economic period. From 1985 to 1994, Brazil had four different currencies (Cruzado, Cruzado Novo, Cruzeiro, and Cruzeiro Real). The country suffered with hyperinflation that reached levels as high as of 81.3 percent in a single month in 1990 (Bresser, Pereira, and Nakano 1991). Budget data for this period is scarce and unreliable. For these reasons we exclude 1986 to 1994 from our analysis.

\section{Malta}

Malta was under direct rule of the British Crown since 1800. British troops were called to liberate the island from the Napoleonic army after only two years of French domination, which in turn had posed an end to the unique confederal theocracy of the Order of St. John, known as the government of the Knights. When the British took over Malta, they centralized decisions under their authority. Ever since, the political history of colonial Malta was one of continuous requests of self-government by the Maltese, and reluctant, intermittent concessions by the UK (Frendo 2000).

The British rule of the first decades was effectively a 'gubernatorial autocracy' (Cremona 1997). Representatives of the Maltese population were kept out of any decision-making body, and civil liberties were suppressed. The King bluntly rejected the requests of constitutional government, representative political bodies, independent tribunals, and freedom of expression. Representation in a consultative Council of Government with consultative powers was first granted in 1835; Maltese members, however, were a minority, and they were appointed rather than elected.

respect for indigenous rights, and corruption within the federal government. From 2003 on, Freedom House ranks the country as Free due to improvements in political rights. In particular, Freedom House highlights the holding of a free and fair election in which an oppositional presidential candidate of a different ideology from the ruling coalition (Luiz Inácio Lula da Silva, Workers' Party) was elected. 
The first elected Council of Government was introduced with the 1849 constitution.

Maltese representatives were still a minority of the members, and suffrage was limited by sex, age, literacy, property, and income; which restricted the electorate to less than four percent of the population. In addition, while the Council had decision-making power, the Governor could override its deliberations. A new constitution granted in 1887 established a Legislative Council with a majority of elected Maltese representatives. However, the Governor could still veto or override its decisions, and while limitations to suffrage were relaxed, the electoral body was still restricted to five percent of the population. When the elected members took a confrontational stand against the colonial government, the constitution was revoked.

A real change was introduced in 1921, when social pressures created by WWI led to the promulgation of a new constitution. The Amery-Milner constitution introduced a bicameral system with legislative powers. A number of matters - including trade, foreign relations and defence - were reserved to the Imperial government; and suffrage was still restricted, including by sex. And yet, the 1921 constitution marked a radical change with the introduction of self-rule. The next significant changed happened in 1947, when a national assembly approved a new constitution which introduced universal suffrage and restricted the reserved matters to those touching 'public safety'.

While post-second world war Malta had fully representative institutions, it still was a British colony. The 1961 Constitution finally established 'the state of Malta' which obtained independence from Britain on 21 September 1964 following a referendum. The Constitution was amended in 1974 to make Malta a Republic. Although Malta had a democratic constitution, a free press, and a pluralistic party system, the first decades after independence were years of democratic consolidation. Its perfect two-party system, coupled with hyper-majoritarian political 
institutions (Carammia and Pace 2015), meant that one party could rule the country after winning the elections by narrow margins of as little as one thousand votes. The charismatic government of Dom Mintoff, the leader of the Labour party in government between 1971 and 1987, was particularly controversial. Mintoff steered Malta toward the non-aligned movement, and tightened relations with such countries as Libya and North Korea. Eventually, civil liberties were tightened during the final years of Labour government. This reflects in Freedom House rankings, where Malta is classified as Partly-Free between 1983 and 1987. That was a short parenthesis, however; for the rest of the period covered by Freedom House, independent Malta was always classified as a free country. In 2004, forty years after gaining independence, Malta became a member of the European Union; four years later, it introduced the Euro as its currency.

\section{References}

Akyüz, Y. and Boratav, K., (2003) 'The making of the Turkish financial crisis'. World

Development, 31(9), pp.1549-1566.

Baer, Werner. (2014) The Brazilian Economy - Growth and Development, Boulder, CO: Lynne Rienner Publishers.

Bresser Pereira, Luiz Carlos, and Yoshiaki Nakano. (1991) 'Hiperinflação e estabilização no Brasil: o primeiro Plano Collor', Revista de Economia Política 11(4): 89-114.

Carammia M. and Pace, R., (2015) 'Malta', in J. M. De Waele, N. Brack, J.-B. Pilet (ed.), Les Democraties Europeennes, Paris: Armand Colin.

Carothers, T. (2002) 'The End of the Transition Paradigm', Journal of Democracy 13: 5-21.

Celasun, O., (1998) ‘The 1994 currency crisis in Turkey’ (No. 1913). World Bank, Development Research Group. 
Cooper, J. (2007). 'Military expenditure in the three-year federal budget of the Russian Federation, 2008-10', available at http://kms2.isn.ethz.ch/serviceengine/Files/ESDP/96405/ipublicationdocument_singledoc ument/be712761-0db9-4536-ba5e49cde3c19695/en/2007_10_cooper20071010\%5B1\%5D.pdf (accessed 20 November 2016).

Coppedge, Michael, John Gerring, Staffan I. Lindberg, Svend-Erik Skaaning, Jan Teorell, Frida Andersson, Kyle L. Marquardt, Valeriya Mechkova, Farhad Miri, Daniel Pemstein, Josefine Pernes, Natalia Stepanova, Eitan Tzelgov, and Yi-ting Wang. (2015b) 'V-Dem Methodology v5', Varieties of Democracy (V-Dem) Project.

Coppedge, Michael, John Gerring, Staffan I. Lindberg, Svend-Erik Skaaning, Jan Teorell, with David Altman, Michael Bernhard, M. Steven Fish, Adam Glynn, Allen Hicken, Carl Henrik Knutsen, Kelly McMann, Pamela Paxton, Daniel Pemstein, Jeffrey Staton, Brigitte Zimmerman, Frida Andersson, Valeriya Mechkova, and Farhad Miri. (2015a) 'V-Dem Codebook v5', Varieties of Democracy (V-Dem) Project.

Cremona, J.J. (1997) The Maltese Constitution and Constitutional History since 1813, Valletta: PEG.

Ergil, D. (2000) 'The Kurdish Question in Turkey', Journal of Democracy, 11(3): 122-35.

Freedom House (1999) Freedom in the World, available at https://freedomhouse.org/report/freedom-world/1999/turkey\#.VXobt0IxFp8 (accessed 11 June 2015). 
Freedom House (2005) Freedom in the World, available at https://freedomhouse.org/report/freedom-world/2005/russia\#.VXLf2FxViko (accessed 6 June 2015).

Frendo, H. (2000) The Origins of Maltese Statehood: A Case Study of Decolonization in the Mediterranean, Valletta: PEG.

Huntington, Samuel P. (1991) The Third Wave - Democratization in the Late Twentieth Century. Norman: University of Oklahoma Press.

Macovei, M., (2009) 'Growth and economic crises in Turkey: leaving behind a turbulent past?' (No. 386). Directorate General Economic and Financial Affairs (DG ECFIN), European Commission.

Marshall, Monty G., Ted Robert Gurr, and Keith Jaggers. (2013) Polity IV Project: Data Users' Manual, Center for Systemic Peace.

Öniş, Z., (2009) 'Beyond the 2001 financial crisis: The political economy of the new phase of neo-liberal restructuring in Turkey.' Review of International Political Economy, 16(3), pp.409-432.

Özatay, F. and Sak, G., (2002) ‘The 2000-2001 financial crisis in Turkey’. In Brookings Trade Forum (pp. 121-160).

Pemstein, Daniel, Stephen A. Meserve, and James Melton. (2010) 'Democratic Compromise: A Latent Variable Analysis of Ten Measures of Regime Type', Political Analysis 18 (4): 426-49.

Shaw, S.J. and Shaw, E.K., 1977. History of the Ottoman Empire and Modern Turkey: Volume 2, Reform, Revolution, and Republic: The Rise of Modern Turkey 1808-1975 (Vol. 11). Güran, Cambridge University Press. 
Skidmore, Thomas E. (1988) The Politics of the Military Rule in Brazil: 1964-1985, New York: Oxford University Press.

Skidmore, Thomas E. (1988) The Politics of the Military Rule in Brazil: 1964-1985, New York: Oxford University Press.

Skidmore, Thomas E., Peter H. Smith, and James N. Green. (2010) Modern Latin America. Oxford: Oxford University Press.

Tachau, F., \& Heper, M. (1983) 'The State, Politics, and the Military in Turkey', Comparative Politics, 17-33.

Toshniwal, Gaurav. (2012) 'Brazil and Russia During the Financial Crisis: A Tale of Two Commodity Exporters.' Harvard Business Law Review, Vol. 2, 199-234.

Troxel, T. (2003) Parliamentary power in Russia, 1994-2001: President vs. parliament, Basingstoke; New York, NY: Palgrave Macmillan.

Wehner, J., and P. Renzio. (2013) 'Citizens, legislators, and executive disclosure: The political determinants of fiscal transparency', World Development 41: 96-108. 